\title{
Epidemiological and genetic analyses of Hepatitis $C$ virus transmission among young/short- and long-term injecting drug users from Rio de Janeiro, Brazil
}

\author{
Maria de Lourdes Aguiar Oliveira ${ }^{\mathrm{a}, *}$, Francisco Inácio Bastos ${ }^{\mathrm{b}}$, Paulo Roberto Telles ${ }^{\mathrm{c}}$, \\ Mariana de Andréa Hacker ${ }^{\mathrm{d}}$, Sabrina Alberti Nóbrega de Oliveira ${ }^{\mathrm{e}}$, \\ Juliana Custódio Miguel $^{\mathrm{e}}$, Clara Fumiko Tachibana Yoshida ${ }^{\mathrm{e}}$ \\ a National Reference Laboratory for Viral Hepatitis \& National Reference Laboratory for Influenza and Exanthematic Diseases, \\ Oswaldo Cruz Institute, Oswaldo Cruz Foundation, Rio de Janeiro, Brazil \\ ${ }^{\mathrm{b}}$ Department of Health Information, Oswaldo Cruz Foundation, Rio de Janeiro, Brazil \\ c Harm Reduction Initiative (NEPAD), State University of Rio de Janeiro, Rio de Janeiro, Brazil \\ ${ }^{\mathrm{d}}$ Laboratory of Leprosy, Oswaldo Cruz Institute, Oswaldo Cruz Foundation, Rio de Janeiro, Brazil \\ e National Reference Laboratory for Viral Hepatitis, Oswaldo Cruz Institute, Oswaldo Cruz Foundation, Rio de Janeiro, Brazil
}

\section{A R T I C L E I N F O}

\section{Article history:}

Received 4 July 2008

Received in revised form 7 November 2008

Accepted 18 December 2008

\section{Keywords:}

Injecting drug use

Substance abuse

Hepatitis C virus

HCV epidemiology

HCV subtypes

Phylogenetic analysis

\begin{abstract}
A B S T R A C T
Background: Injecting drug users (IDU) have a key role in Hepatitis C Virus (HCV) epidemiology. Young/short-term IDUs constitute a target group for preventive/harm reduction interventions.

Objectives: To investigate HCV transmission among young/short-term (ST) and long-term (LT) IDUs, from the perspective of epidemiology and molecular biology.

Study design: Cross-sectional study assessing the prevalence of HCV infection/genotypes, as well as risk behaviours/practices among IDUs from Rio de Janeiro. Phylogenetic analyses were performed and the extent of segregation between sequences was quantified by the Association Index.

Results: ST were more likely to engage into needle-sharing $(p=.021)$ and LT to attend Needle Exchange Programs $(p=.006)$. HCV prevalence was $10.1 \%$ vs. $23.4 \%$ among initiates and LT, respectively $(p<.001)$. Older age vs. imprisonment and longer duration of IDU career were independent predictors for HCV infection among ST and LT, respectively. Among the latter, NEP attendance was inversely associated with viral infection. HCV3a infections were the most prevalent. A moderate extent of phylogenetic segregation between sequences was found, suggestive of transmission between IDU subgroups.

Conclusions: The lower HCV prevalence among young/short-term IDUs cannot be viewed with complacency, due to their frequent engagement into direct/indirect sharing practices and the ongoing transmission between IDU subsets. To avert new infections, preventive/harm reduction policies must be tailored to empirical findings.
\end{abstract}

(c) 2008 Elsevier B.V. All rights reserved.

\section{Introduction}

Worldwide, Hepatitis C Virus (HCV) infection is a public health challenge, due to its health and economical impacts. ${ }^{1}$ About $60-85 \%$ of infected-subjects develop chronic infection, of which major complications are liver cirrhosis and hepatocarcinoma. ${ }^{2}$

In the last decades, HCV epidemiology has been changing in developed countries, due to improved blood transfusion safety

\footnotetext{
* Corresponding author at: Laboratório de Vírus Respiratórios e do Sarampo, Instituto Oswaldo Cruz, Fiocruz, Pavilhão Helio e Peggy Pereira, sala B-105, Avenida Brazil 4365, Manguinhos, Rio de Janeiro, CEP 21040-360, Brazil.

E-mail addresses: mlaoliveira@fiocruz.br, mlaoliveira@uol.com.br (M.L.A. Oliveira), bastos@cict.fiocruz.br (F.I. Bastos), prtelles25@terra.com.br (P.R. Telles), marianah@ioc.fiocruz.br (M.A. Hacker), salberti@ioc.fiocruz.br (S.A.N. Oliveira), julicm@ioc.fiocruz.br (J.C. Miguel), yoshida@ioc.fiocruz.br (C.F.T. Yoshida).
}

and better healthcare conditions. Consequently, injection drug use became the main mode of viral transmission and accounts for more than $60 \%$ of prevalent cases in Europe. ${ }^{3}$

Drug injectors are frequently engaged into risky behaviours, ${ }^{4-6}$ favouring an extensive HCV spread throughout IDUs networks. ${ }^{7}$ Many new infections occur in young/new IDU, among whom incidence rates from 11.6 to $37.3 / 100$ persons-year have been described. ${ }^{8,9}$

HCV is classified into six major genotypes and several subtypes, ${ }^{10}$ which present distinct geographical patterns and response to antiviral therapy. ${ }^{11}$ Moreover, a relationship between viral variants and mode of transmission has been shown. ${ }^{12,13}$ Changing patterns/introduction of new subtypes can ensue relatively fast within IDU networks. ${ }^{3}$

In this study, practices and behaviours and their putative association with HCV infection/genotypes were investigated among young/short- and long-term IDUs. Phylogenetic relationships 
between IDU sequences and the extent of transmission between both subsets were also analyzed. This information is unavailable in Brazil, although critical to avert harmful practices among initiates.

\section{Methods}

\subsection{Population}

From 1999 to 2001, 606 IDUs were recruited in the Rio de Janeiro's “drug scenes", as previously described. ${ }^{14}$ After signing an informed consent, volunteers were interviewed using a structured questionnaire standardized by the World Health Organization (WHO) $)^{15}$ and a blood sample was collected.

All interviewees received pre-/post-test counselling and were referred to Health Services, if viral RNA-positive. HBV vaccination was also available. The study was approved by the Oswaldo Cruz Foundation's Human Subjects Protection Committee.

IDUs were grouped into short-(ST) and long-term injectors (LT), according to the number of years of drug injection (equal or less vs. more than 6 years, respectively). The rationale for this cutoff ${ }^{16}$ and definitions for other variables are explained elsewhere. ${ }^{14}$

\subsection{Laboratory methods}

HCV antibodies were detected by an immunoassay (UBI HCV EIA 4.0, Beijing United). Viral RNA was extracted using QIAamp ${ }^{\circledR}$ Viral RNA extraction kit (QIAgen). Detection of 5'NCR HCV-RNA was performed as previously described. ${ }^{17}$ For NS5b, one-step PCR was carried out using the SuperScript ${ }^{\mathrm{TM}}$ III One-Step RT-PCR System (Invitrogen). Termocycling conditions consisted of 1 cycle$42^{\circ} \mathrm{C} / 45 \mathrm{~min}$; followed by 1 cycle- $95^{\circ} \mathrm{C} / 4 \mathrm{~min} ; 40$ cycles- $95^{\circ} \mathrm{C} / 20 \mathrm{~s}$; $54^{\circ} \mathrm{C} / 30 \mathrm{~s} ; 72^{\circ} \mathrm{C} / 1 \mathrm{~min}$ and a final extension cycle $\left(72^{\circ} \mathrm{C} / 10 \mathrm{~min}\right)$. For nested PCR, $1 \mu \mathrm{l}$ of first PCR product was used. Primers and nested-PCR protocol were already published. ${ }^{18}$

PCR products were sequenced in sense and antisense directions (BigDye sequencing kit 3.1, Applied Biosystems) and analyzed with ABI 3730 automated DNA sequencer. 5'ÚTR and NS5b sequences spanned nucleotide positions 49-287 and 8277-8606, respectively ${ }^{19}$. Clustal X was used for DNA alignment.

\subsection{Phylogenetic and molecular evolutionary analyses}

Analyses were performed using MEGA 4.0. ${ }^{20}$ Phylogenetic trees were constructed using the Neighbor-Joining method, ${ }^{21}$ with bootstrap re-sampling (1000 replicates). ${ }^{22}$ Evolutionary distances were computed using the Kimura 2-parameter method. ${ }^{23}$ Standard error estimates were obtained by a bootstrap procedure (1000 replicates).

\subsection{Assessment of genetic isolation between ST and LT IDU sequences}

The degree to which viruses circulating among ST IDUs were phylogenetically distinct from those found among LT IDUs was measured by the Association Index (AI), which quantifies the degree of phylogenetic segregation between groups of sequences. ${ }^{24,25,26}$ Briefly, sequences were labelled according to their subgroup (ST vs. LT) and used to construct 2 subsets of phylogenetic trees: "observed" and "control". The first was used to infer phylogenetic segregation while the second determined how often segregation may occur by chance. AI expresses the ratio of the median association values of the "observed" against the "control" trees. Values close to 0 represent complete segregation, whereas values $\geq 1$ correspond to complete phylogenetic mix- ing. Analyses were performed using the Simmonic 2005 v.1.6 software. $^{27}$

\subsection{Statistical analyses}

Contingence table statistics (Chi-square or Fisher's exact test, and t-tests for means) were employed to assess associations between socio-demographic/behavioural variables and HCV infection/viral genotypes. All variables of epidemiological relevance with $p<0.10$ in bivariate analyses were entered into multivariable logistic regression. The Wilcoxon test was used for comparison between observed and control association values.

\section{Results}

\subsection{Epidemiological findings}

Socio-demographic features, drug use and sexual behaviours and HCV infection/viral genotypes prevalence among short-and long-term injectors are shown in Table 1 . Two-hundred ninety nine and 307 interviewees were grouped as short- and long-term injectors, with a mean duration of injection of 2.2 vs.16.1 years $(p<.001)$ and a median year of first injection of 1997 vs. $1986(p<.001)$, respectively. ST were significantly younger and more likely to be single, compared to their counterparts. About half of the interviewees had a low education background and most interviewees reported informal activities as their main source of income.

Detention was mentioned by roughly half of the sample. LT were more likely than ST to share injection equipment while imprisoned.

For both groups, cocaine was the drug of choice and noninjection use the main mode of drug intake. Higher injection frequencies were found among LT IDUs, whereas short-term injectors reported a significantly higher frequency of syringe/needle-sharing $(p=.021)$. Indirect sharing practices were reported by both subgroups under similar frequencies. Unprotected sex was common, irrespectively of the nature of partnership or sexual orientation.

LT were less likely than ST IDUs to have been treated for drug abuse $(p=.003)$. In contrast, they reported a higher attendance of Needle Exchange Programs (NEPs) $(p=.006)$.

The overall prevalence of HCV infections was $16.9 \%$ and LT IDUs were 2.7 times more likely to be infected with HCV than new injectors $(p<.001)$ (Table 1$)$. In bivariate analyses, variables that were significantly associated with viral infection were: "sexual intercourse with casual partners from the opposite sex in the last 6 months" $(p=.024)$, "male-to-male sex" $(p=.025)$, "older age" $(p<.001)$ and "more years of full education" $(p=.005)$ among shortterm IDU, vs. "daily frequency of injection" $(p=.001)$, "ever been in prison" ( $p=.001)$; "injection with an HIV-infected IDU" $(p=.002)$, "older age" $(p<.001)$, "younger age of first injection" $(p=.002)$ and "duration of injection drug use" $(p<.001)$ among long-term drug injectors. Finally, "attendance in Needle Exchange Programs in the last 6 months" was found to be a protective factor for HCV infection ( $\mathrm{OR}=0.2 ; p=.015)$. Independent predictors for HCV infection among ST and LT IDUs are shown in Table 2.

\subsection{Molecular findings}

Viral RNA (5'UTR) was detected in 74.5\% (76/102) of anti-HCV positive samples, from which 74 (97.4\%) had their HCV subtype determined. Two samples were not sequenced due to a weak PCR product signal. NS5b nested-PCR was carried out in 76 samples, from which only 47 (61.8\%) showed reactivity; even after retesting since RNA extraction. A similar distribution of viral genotypes was observed in both IDU subgroups (Table 1). Finally, none association was found between viral variants and epidemiological data. 
Table 1

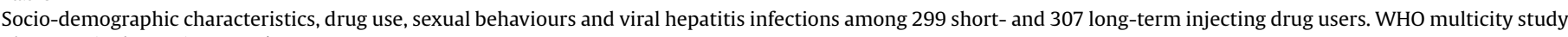
Phase II, Rio de Janeiro, 1999/2001.

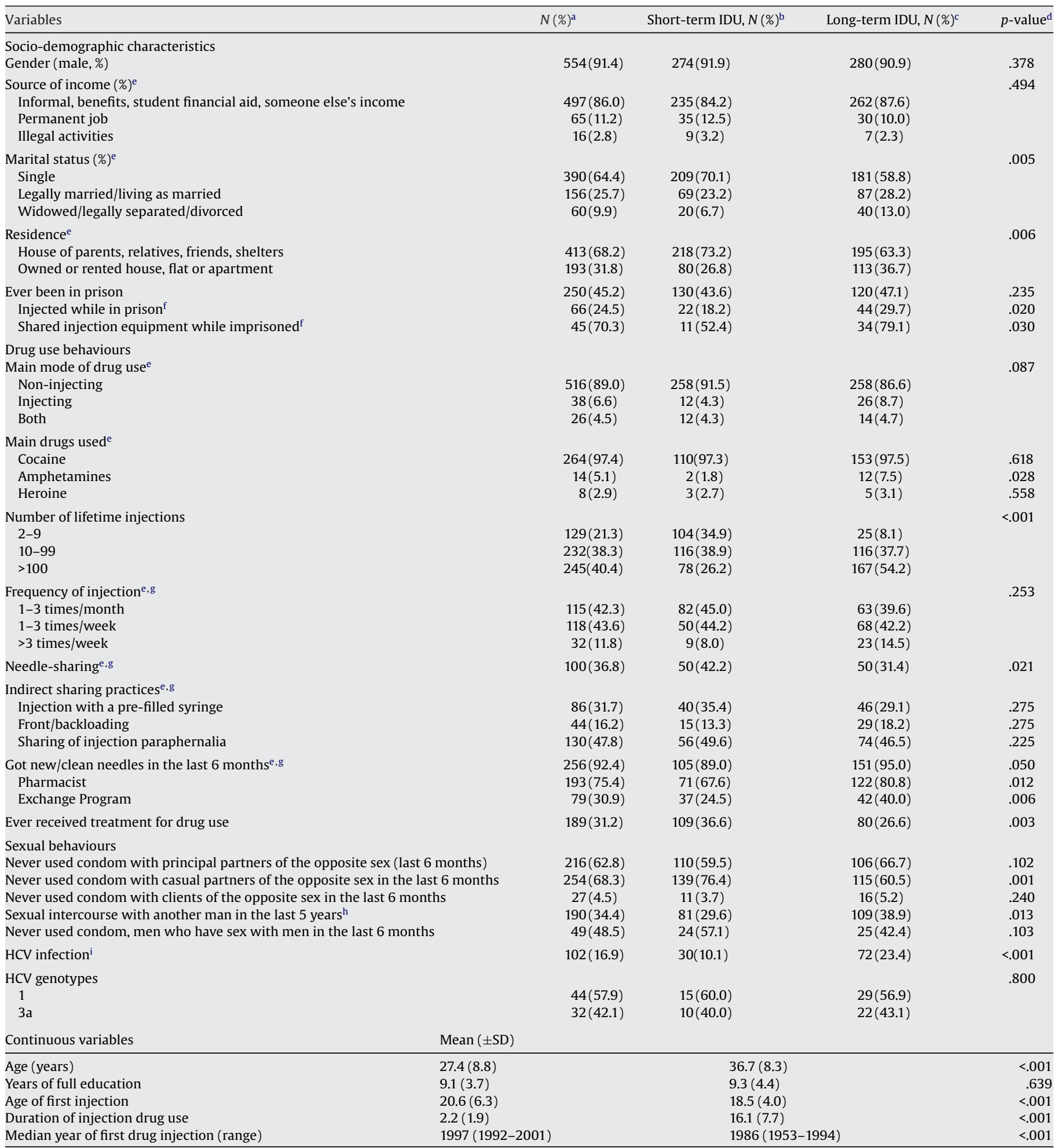

Short-term IDUs were defined as those who inject illicit drugs for less than 6 years.

a Total $=606$ subjects.

b $N=299$.

c $N=307$.

d Significance was considered when $p$-value $<.005$.

e Last 6 months.

${ }^{\mathrm{f}}$ Among 66 interviewees who shared needles/syringes while imprisoned who shared needles/syringes in prison.

g Among 272 active IDUs, who injected drugs in the last 6 months (short-term, 113 and long-terms, 159).

h Among 554 men (short-term-274; long-term-280).

i $\mathrm{HCV}[\mathrm{OR}=2.7(1.7-4.3)]$. 
Table 2

Independent predictors for HCV infection among 299 short- and 308 long-term injecting drug users. WHO multicity study Phase II, Rio de Janeiro, 1999/2001.

\begin{tabular}{lcc}
\hline Variables & AdjOR $(95 \% \mathrm{CI})$ & $p$-value \\
\hline $\begin{array}{l}\text { Short-term IDU } \\
\text { Older age }\end{array}$ & $1.14(1.09-1.20)$ & $<.001$ \\
Long-term IDU $^{\mathrm{b}}$ & & \\
Duration of injection drug use $_{\text {Ever been in prison }}$ & $1.12(1.07-1.18)$ & $<.001$ \\
Attendance in needle exchange program $^{\mathrm{c}}$ & $3.19(1.23-8.24)$ & .017 \\
\hline
\end{tabular}

Short-term IDUs are defined as those who inject drugs for less than 6 years.

a Final model: $\chi^{2}=40.0 ; p<.001$.

b Final model $\chi^{2}=49.4 ; p<.001$.

${ }^{c}$ In the last 6 months.

Some facts speak in favour of dissimilar results between ST and LT, including: i) the different behavioural profiles of ST and LT may lead to different phylogenetically-related groups; ii) time of first injection was markedly different for ST and LT (consequently, changes in the background genotype distribution over time).

However, analyses of mean pairwise evolutionary distances showed similar results for ST and LT NS5b sequences. Within HCV subtypes $1 \mathrm{a}, 1 \mathrm{~b}$ and $3 \mathrm{a}$, the mean evolutionary distances (standard error) were 0.027 (0.005), 0.085 (0.012) and 0.054 (0.009) vs. 0.038 (0.006), 0.082 (0.011) and 0.048 (0.007) among short- and longterm IDUs, respectively. Thus, a more detailed assessment of HCV phylogenetic profile of the two subgroups was performed.

Phylogenetic relationships between IDU sequences are shown in Fig. 1. Except for two related pairs (one for subtype 1a and another for subtype 3a), with high bootstrap values, sequences from both subsets were dispersed along the reconstructed trees, corroborating previous findings.

The extent of segregation between ST and LT IDU sequences, measured in terms of AI, is shown in Table 3. HCV1a and 3a sequences showed slightly lower AI values, compared to HCV1b. Indeed, in agreement with evolutionary distance data, a considerable phylogenetic mixing between IDU sequences was observed, what may be explained by frequent (but not free) transmission within IDU strata. Moreover, since AI values were $<1$, there is some segregation between IDU subsets, with the rejection of the null hypothesis (no difference between observed and control AIs) $(p<.001$ for HCV1a and 3a and $p=.013$ for HCV1b)

\section{Discussion}

In this study, epidemiological and molecular patterns of HCV transmission among short- and long-term IDUs were assessed. These are pivotal information to provide the basis for sound preventive policies, management and care of such population.

Table 3

Association indices and association values in short- and long-term injecting drug users sequences, according to HCV subtype and genome region.

\begin{tabular}{|c|c|c|c|}
\hline \multirow[t]{2}{*}{ Sequences compared } & \multicolumn{2}{|c|}{ Median association values } & \multirow[t]{2}{*}{ Association index } \\
\hline & Observed & Controls & \\
\hline \multicolumn{4}{|c|}{ Short- and long-term IDUs-5'UTR } \\
\hline HCV 1a & 1.33 & 2.09 & 0.63 \\
\hline HCV 1b & 1.33 & 1.62 & 0.70 \\
\hline HCV 3a & 1.32 & 2.03 & 0.65 \\
\hline \multicolumn{4}{|c|}{ Short- and long-term IDUs-NS5 $\mathrm{b}^{*}$} \\
\hline HCV 1a & 0.42 & 0.74 & 0.56 \\
\hline HCV 1b & 0.48 & 0.67 & 0.72 \\
\hline HCV 3a & 0.50 & 0.73 & 0.69 \\
\hline
\end{tabular}

${ }^{a}$ For all tested samples. Association values and AI were calculated using the program Simmonic 2005 v.1.6 ${ }^{27}$.
Despite the efforts to obtain a representative sample of Rio de Janeiro's drug scenes, findings cannot be generalized to the IDU population. Moreover, as prevalence of HCV infection was significantly lower than expected, for some variables, a tiny sample remained after stratification, precluding the assessment of some putative associations.

According to the international literature, ${ }^{28,29}$ short-term injectors reported significantly higher frequencies of syringe/needlesharing than long-term IDUs. Furthermore, a high frequency of indirect sharing practices has been also noticed. This is a key problem to be tackled, since both direct and indirect sharing practices are associated with extensive HCV transmission within IDU networks. 5,30

The prevalence of HCV infection was significantly lower than previously found in the same population and setting. ${ }^{31}$ Possible reasons for this scenario are discussed elsewhere. ${ }^{32}$ Besides this declining trend, drug injection started at an older age among initiates in recent years, calling for timely intervention.

Imprisonment and longer duration of injection drug use were independent predictors of $\mathrm{HCV}$ infection. Association between imprisonment and HCV infection is common among IDUs ${ }^{33,34}$ and the second is a major determinant for HCV infection worldwide. ${ }^{35}$ Among short-term IDU from Vancouver, for each two additional years of drug injection, the risk for HCV infection had doubled. ${ }^{8}$

LT IDUs who attended NEPs were significantly less likely to be HCV-infected. Declining rates of HCV infection as a benefit of NEP attendance have been described. ${ }^{36}$ However, young IDUs have been pointed as particularly susceptible to HIV infection because of inexperience in obtaining clean injection equipment. ${ }^{37}$ Our observations seem to corroborate these remarks.

Regardless of sexual orientation/kind of partnership, unprotected sex was frequent, as usually reported among cocaine users. ${ }^{38}$ HCV is not efficiently transmitted by sexual intercourse and the literature on this issue remains controversial. However, HIV infection seems to favour the sexual transmission of HCV. ${ }^{39}$ Higher odds for HCV infection were observed among ST IDUs reporting unprotected sex with both men and women engaged with casual partners. Although these associations did not remain significant after controlling for possible confounders, we cannot rule out the possibility of sexual transmission among these subjects.

Interestingly, a considerable lower rate of HCV-RNA amplification for NS5b region was obtained among IDU samples from Rio de Janeiro, when compared to IDU samples from São Paulo (62\% vs. $90 \%$, respectively; data not shown). Nevertheless, samples were positive for 5' UTR HCV-RNA and remained NS5b negative, even after retesting. One of the possible explanations for the low amplification frequency of NS5b fragments could be the mismatch of primers, due to heterologous sequences. Sequencing of other fragments/regions could be helpful to elucidate these findings.

The distribution of HCV genotypes corroborates previous findings. ${ }^{40,31}$ However, it differed substantially from those observed among chronic patients from Rio de Janeiro, where HCV1b infections are more prevalent. ${ }^{41}$ The extent to which HCV circulating among new injectors was phylogenetically distant from those circulating within long-term IDU was measured in terms of AI. These analyses suggest a moderate level of virus exchange between IDU subgroups. Although not significantly different, segregation was higher among HCV1a, whereas a higher phylogenetic mixing was found among HCV1b sequences. If we use the year of first injection as a proxy of the year IDUs became infected, HCV1b infections seems to be introduced earlier, as the most prevalent genotype in the $1960 \mathrm{~s}$, whereas HCV1a infections seems to have emerged in the early $1970 \mathrm{~s}$. Thus, we may speculate that the higher segregation of HCV1a sequences could be partially attributed to a later entrance and dissemination within our IDU sample. Indeed, a study on the epidemic history of HCV estimated that subtypes 1a and 

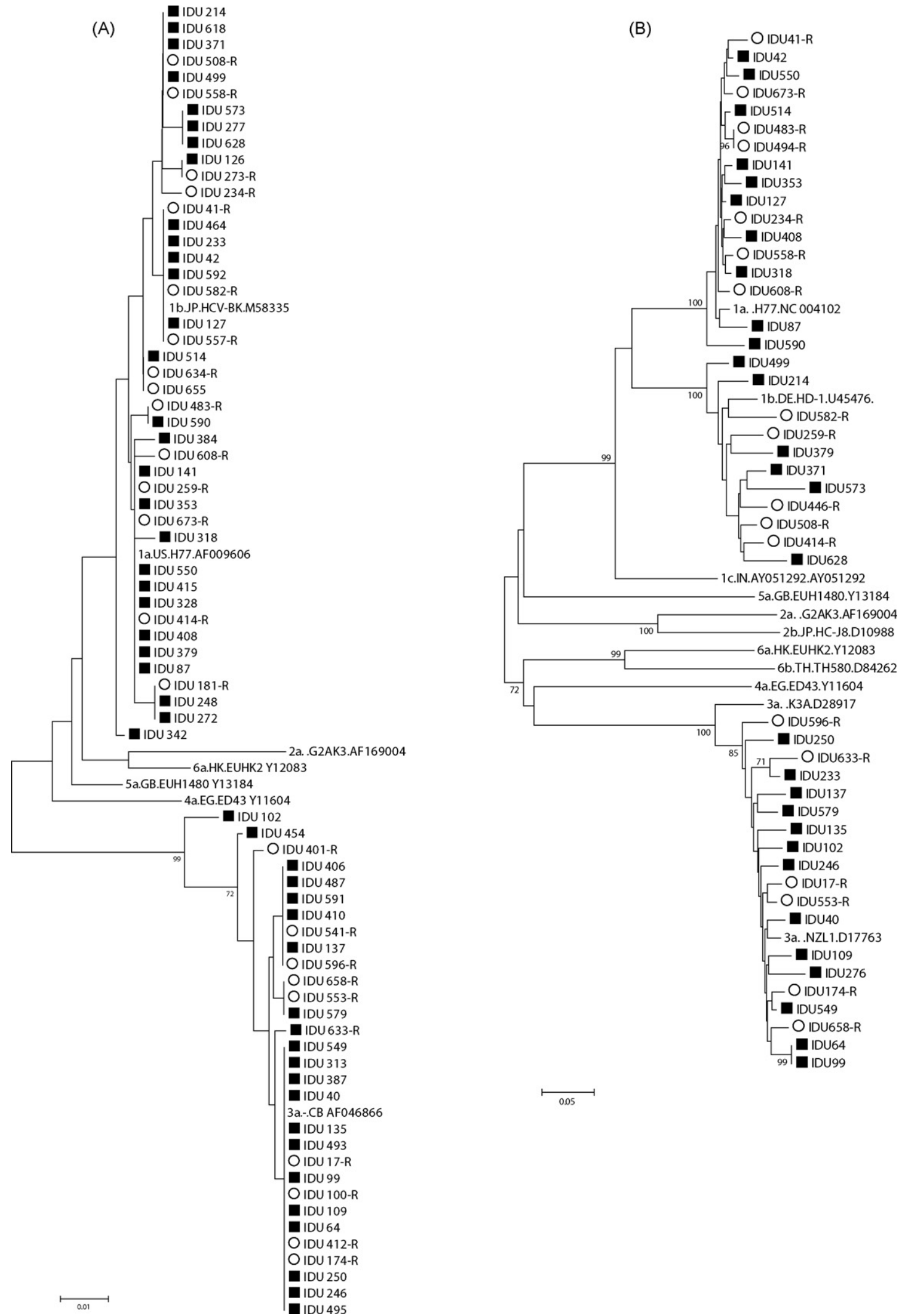

Fig. 1. The evolutionary history of HCV sequences from short-term $(O)$ and long-term $\mathbf{\square})$ injecting drug users for $5^{\prime}$ UTR (A) and NS5b (B) regions was inferred using the Neighbor-Joining method..$^{21}$ The percentage of replicate trees in which the associated taxa clustered together in the bootstrap test (1000 replicates) is shown next to the branches. ${ }^{22}$ The evolutionary distances were computed using the Kimura 2-parameter ${ }^{23}$ and are expressed in the units of the number of base substitutions per site. The accession numbers of reference and IDU sequences used in this study were as follows: 1a (AF009606); 1b (M58335); 1c (AY051292); 2a (AF169004); 2b (AF238486); 2c (D50409); 3a (AF046866); 3b (D49374); 4a (Y11604); 5a (Y13184); 6a (Y12083) and 6b (D84262) and IDUs EU678672 to EU678744 for 5' UTR region and 1a (AF009606); 1b (U45476); 1c (AY051292); 2a (AF169004); 2b (AF238486); 3a (D28917); 3b (D49374); 4a (Y11604); 5a (Y13184); 6a (Y12083) and 6b (D84262) and IDUs EU747741 to EU747787 for NS5b region, respectively. 
1b were introduced in Brazil about 1940-1950 and 1820-1920, respectively. ${ }^{42}$ Finally, segregation could also be attributed to distinct risk behaviour profiles among IDU subgroups, which could eventually favour the transmission of non-1a subtypes in a larger extent.

Altogether, these findings speak in favour of interventions and management strategies tailored to the specificities of young/new injectors. Declining rates of HCV infection should be viewed as a chance for effective and prompt intervention.

\section{Conflict of interest}

None.

\section{Acknowledgments}

This paper is based on the data and experience obtained during the WHO Drug Injection Study Phase II-a project, coordinated and sponsored by the World Health Organization and implemented by the WHO Phase II Drug Injection Collaborative Study Group. The authors alone are responsible for the views expressed in this paper, which do not necessarily represent those of the other investigators participating in the WHO Drug Injection Study Phase II nor the views or policy of the World Health Organization.

The Brazilian component of the study was sponsored by WHO, as well as by the Coordenação Geral de Laboratórios, National Health Foundation, SVS, Ministry of Health and Conselho Nacional de Desenvolvimento Científico e Tecnológico, CNPq, Grant no. 475668/03.

We are grateful to the Harm Reduction Program team for the field work with such hard-to-reach and population; to Aline Santos Moreira, from the Genomic Platform-DNA Sequencing (PDTISFiocruz) for DNA sequencing of samples included in this study and to Dr. José Paulo Leite, Dr. Milton Moraes, Mrs. Marcia Paschoal, and Dr. Elisabeth Lampe, for their helpful suggestions.

\section{References}

1. Brown RS, Gaglio PJ. Scope of worldwide hepatitis C problem. Liver Transpl 2003;9:S10-3.

2. National Institutes of Health; 1 ;. National Institutes of Health Consensus Development Statement: management of hepatitis C 2002; 10-12 June 2002. Hepatology 2002; 36,S3-S20.

3. Esteban JI, Sauleda S, Quer J. The changing epidemiology of hepatitis C virus infection in Europe. J Hepatol 2008;48:148-62.

4. Stark K, Müller R, Bienzle U, Guggenmoos-Holzmann I. Frontloading: a risk factor for HIV and hepatitis $C$ virus infection among injecting drug users in Berlin. AIDS 1996;10:311-7.

5. Hagan H, Thiede H, Weiss NS, Hopkins SG, Duchin JS, Alexander ER. Sharing of drug preparation equipment as a risk factor for hepatitis C. Am J Public Health 2001;91:42-6.

6. Thiede H, Hagan H, Campbell JV, Strathdee SA, Bailey SL, Hudson SM, et al. Prevalence and correlates of indirect sharing practices among young adult injection drug users in five U.S. cities. Drug Alcohol Depend 2007;91: S39-47.

7. Wiessing L, Roy K, Sapinho D, Hay G, Taylor A, Goldberg D et al. Surveillance of hepatitis $C$ infection among injecting drug users in the European Union. In:EMCDDA Scientific Monograph, Series n. 7. Luxembourg Office for Official Publications of the European Communities, 2004. pp: 91-130. Available at http://www.emcdda.eu.int/index.cfm?fuseaction = public.Content\&nNodeID = 6017\&sLanguageISO $=$ EN.

8. Miller CL, Johnston C, Spittal PM, Li K, Laliberté N, Montaner JSG, et al. Opportunities for prevention: hepatitis $C$ prevalence and incidence in a cohort of young injection drug users. Hepatology 2002;36:737-42.

9. Hagan H, Thiede H, Des Jarlais D, Hepatitis C. virus infection among injection drug users: survival analysis of time to seroconversion. Epidemiology 2004:15:543-9.

10. Simmonds P, Holmes EC, Cha TA, Chan SW, McOmish F, Irvine B, et al. Classification of hepatitis $\mathrm{C}$ virus into six major genotypes and a series of subtypes by phylogenetic analysis of NS-5 region. J Gen Virol 1993;74: 2391-9.

11. Simmonds P. Genetic diversity and evolution of hepatitis C virus-15 years on. $J$ Gen Virol 2004;85:3173-88.
12. Oliveira ML, Bastos FI, Sabino RR, Paetzold U, Schreier E, Pauli G, et al. Distribution of HCV genotypes among different exposure categories in Brazil. Braz J Med Biol Res 1999;32:279-82.

13. Matheï C, Wollants E, Verbeeck J, Ranst MV, Robaeys G, Damme PV, et al. Molecular epidemiology of hepatitis C among drug users in Flanders, Belgium: association of genotype with clinical parameters and with sexand drug-related risk behaviours. Eur J Clin Microbiol Infect Dis 2005;24 $514-22$.

14. Oliveira ML, Hacker MA, Oliveira SA, Telles PR, O KM, Yoshida CF et al. The first shot: the context of first injection of illicit drugs, ongoing injecting practices, and hepatitis C infection in Rio de Janeiro, Brazil. Cad Saude Publica 22, (2006) 861-70.

15. Des Jarlais DC, Perlis TE, Stimson GV, Poznyak V. WHO Phase II drug injection collaborative study group. Using standardized methods for research on HIV and injecting drug use in developing/transitional countries: case study from the WHO drug injection study Phase II. BMC Public Health 2006;6: 54.

16. Hacker MA, Friedman SR, Telles PR, Teixeira SL, Bongertz V, Morgado MG, et al The role of "long-term" and "new" injectors in a declining HIV/AIDS epidemic in Rio de Janeiro. Brazil Subst Use Misuse 2005;40:99-123.

17. de Oliveira JM, Rispeter K, Viazov S, Saback FL, Roggendorf M, Yoshida CF. Differences in HCV antibody patterns in haemodialysis patients infected with the same virus isolate. J Med Virol 2001;63:265-70.

18. Chen Z, Weck K. Hepatitis C virus genotyping: interrogation of the $5^{\prime}$ untranslated region cannot accurately distinguish genotypes 1a and 1b. J Clin Microbiol 2002;40:3127-34.

19. Kuiken C, Combet C, Bukh J, Shin-I T, Deleage G, Mizokami M, et al. A comprehensive system for consistent numbering of HCV sequences, proteins and epitopes. Hepatology 2006;44:1355-61.

20. Tamura K, Dudley J, Nei M, Kumar S. MEGA4: Molecular Evolutionary Genetics Analysis (MEGA) software version 4.0. Mol Biol Evol 2007;24: 1596-9.

21. Saitou N, Nei M. The neighbor-joining method: a new method for reconstructing phylogenetic trees. Mol Biol Evol 1987;4:406-25.

22. Felsenstein J. Confidence limits on phylogenies: an approach using the bootstrap. Evolution 1985;39:783-91.

23. Kimura M. A simple method for estimating evolutionary rate of base substitutions through comparative studies of nucleotide sequences. J Mol Evol 1980;16:111-20.

24. Wang TH, Donaldson YK, Brettle RP, Bell JE, Simmonds P. Identification of shared populations of human immunodeficiency virus type 1 infecting microglia and tissue macrophages outside the central nervous system.J Virol 2001;75:686-99.

25. Cochrane A, Searle B, Hardie A, Robertson R, Delahooke T, Cameron S, et al. A genetic analysis of hepatitis $C$ virus transmission between injection drug users. J Infect Dis 2002;186:1212-21.

26. Matheï C, Van Dooren S, Lemey P, Van Damme P, Buntinx F, Vandamme AM. The epidemic history of hepatitis $C$ among injecting drug users in Flanders, Belgium. J Viral Hepat 2008;15:399-408.

27. Simmonds P, Smith DB. Structural constraints on RNA virus evolution. J Virol 1999;73:5787-94.

28. Buxton MB, Vlahov D, Strathdee SA, Des Jarlais D, Morse EV, Ouellet L, et al. Association between injection practices and duration of injection among recently initiated injection drug users. Drug Alcohol Depend 2004;75: 177-83.

29. Maher L, Li J, Jalaludin B, Chant KG, Kaldor JM. High hepatitis C incidence in new injecting drug users: a policy failure. Aust N Z J Public Health 2007;31(1): 30-5.

30. Thorpe LE, Ouellet LJ, Hershow R, Bailey SL, Williams IT, Williamson J, et al. Risk of hepatitis $C$ virus infection among young adult injection drug users who share injection equipment. Am J Epidemiol 2002;155:645-53.

31. Oliveira ML, Bastos FI, Telles PR, Yoshida CF, Schatzmayr HG, Paetzold U, et al. Prevalence and risk factors for HBV, HCV and HDV infections among injecting drug users from Rio de Janeiro. Brazil Braz J Med Biol Res 1999;32: 1107-14.

32. Bastos FI, Bongertz V, Teixeira SL, Morgado MG, Hacker MA. Is human immunodeficiency virus/acquired immunodeficiency syndrome decreasing among Brazilian injection drug users? Recent findings and how to interpret them. Mem Inst Oswaldo Cruz 2005;100:91-6.

33. Stark K, Bienzle U, Vonk R, Guggenmoos-Holzmann I. History of syringe sharing in prison and risk of hepatitis B virus, hepatitis $C$ virus, and human immunodeficiency virus infection among injecting drug users in Berlin. Int J Epidemiol 1997;26:1359-66.

34. Hickman M, Hope V, Brady T, Madden P, Jones S, Honor S, et al. Hepatitis C virus (HCV) prevalence, and injecting risk behaviour in multiple sites in England in 2004. J Viral Hepat 2007;14:645-52.

35. Crofts N, Jolley D, Kaldor J, van Beek I. Epidemiology of hepatitis C virus infection among injecting drug users in Australia. J Epidemiol Community Health 1997;51:692-7.

36. Wright NM, Tompkins CN. A review of the evidence for the effectiveness of primary prevention interventions for hepatitis $C$ among injecting drug users. Harm Reduct J 2006;6:27.

37. World Health Organization. Advocacy guide: HIV/AIDS prevention among injection drug users; 2004.

38. Castilla J, Barrio G, Belza MJ, de la Fuente L. Drug and alcohol consumption and sexual risk behaviour among young adults: results from a national survey. Drug Alcohol Depend 1999;56:47-53. 
39. Cavalheiro NP. Sexual transmission of hepatitis C. Rev Inst Med Trop Sao Paulo 2007;49:271-7.

40. Stark K, Schreier E, Müller R, Wirth D, Driesel G, Bienzle U. Prevalence and determinants of anti-HCV seropositivity and of HCV genotype among intravenous drug users in Berlin. Scand J Infect Dis 1995;27:331-7.
41. Campiotto S, Pinho JRR, Carrilho FJ, Silva LCD, Souto FJD, Spinelli V, et al. Geographic distribution of hepatitis C virus genotypes in Brazil. Braz J Med Biol Res 2005;38:41-9.

42. Nakano T, Lu L, Liu P, Pybus OG. Viral gene sequences reveal the variable history of hepatitis C virus infection among countries. J Infect Dis 2004;190:1098-108. 